\title{
Effect of different levels of selenium on the carcass characteristics of Karadi lambs
}

\author{
A.B. Mahmood ${ }^{1}$, M.K. Arif ${ }^{1}$, S.M. Sadq ${ }^{1 *}$, A.A. Alhoby ${ }^{2}$ and S.A. Abdurahman ${ }^{1}$ \\ ${ }^{1}$ Department of Animal Science, College of Agricultural Sciences, University of Sulaimani, Kurdistan Region, Iraq, \\ ${ }^{2}$ Department of Animal Resources, College of Agriculture, Baghdad University, Baghdad, Iraq \\ *Corresponding author: Email: sarwar.sadq@,univsul.edu.iq
}

(Received September 28, 2017; Accepted November 26, 2017)

\begin{abstract}
This study was conducted to evaluate the effect of using different levels of selenium (Se, Sodium Selenite) on carcass characteristics of Karadi lambs. Fifteen male lambs (4-5 months old and initial weight $25 \pm 0.53 \mathrm{~kg}$ ) were randomly divided into three groups (5 lambs for each). All groups were fed rations consisted mainly of barley grain, wheat bran, yellow corn and soybean meal. All lambs were Se orally given twice a week, which were put in an empty gelatin capsules. The experimental groups were: control group T1 (0 mg Se $/ \mathrm{kg} \mathrm{BW}$ ), low level T2 (0.15 mg Se $/ \mathrm{kg} \mathrm{BW})$ and high level T3 (0.25 mg Se $/ \mathrm{kg} \mathrm{BW})$. The results showed no significant effects of the different amount of Se on slaughter weight (SW), empty body weight (EBW), dressing percentages (hot carcass weight on empty body weight (HCW/EBW), cold carcass weight on SW (CCW/SW) and (CCW/EBW), carcass length and rib eye area, all adipose fat tissues, carcass offal weights and the chemical composition of meat. On the other hand, significant $(\mathrm{P}<0.05)$ differences were found in hot carcass weight $(\mathrm{HCW})$, cold carcass weight $(\mathrm{CCW})$, dressing percentage of $\mathrm{HCW} / \mathrm{SW}$, fat thickness, the loin, rack, flank cuts and fat tail among all treatments. The highest weight of loin, rack, flank and fat tail was found in T3, but the lowest weight was in (T1). The physical dissection of legs for fat $\%$ components was reduced in both Se treatments groups compared to the control groups. The heart, kidneys, spleen and testicular weight were increased significantly $(\mathrm{P}<0.05)$ by increased levels of Se compared to the T1. While, the T2 showed the higher weight of the spleen, but the lower weight was in T1. In conclusion, the increased amount of Se significantly influenced some carcass traits; (HCW), (CCW), dressing percentage of $\mathrm{HCW} / \mathrm{SW}$, some carcass cuts, edible and reduced fat thickness and fat contents of leg dissection.
\end{abstract}

Keywords: Carcass characteristics, Karadi lambs, Sodium selenite Available online at http://www.vetmedmosul.org/ijvs

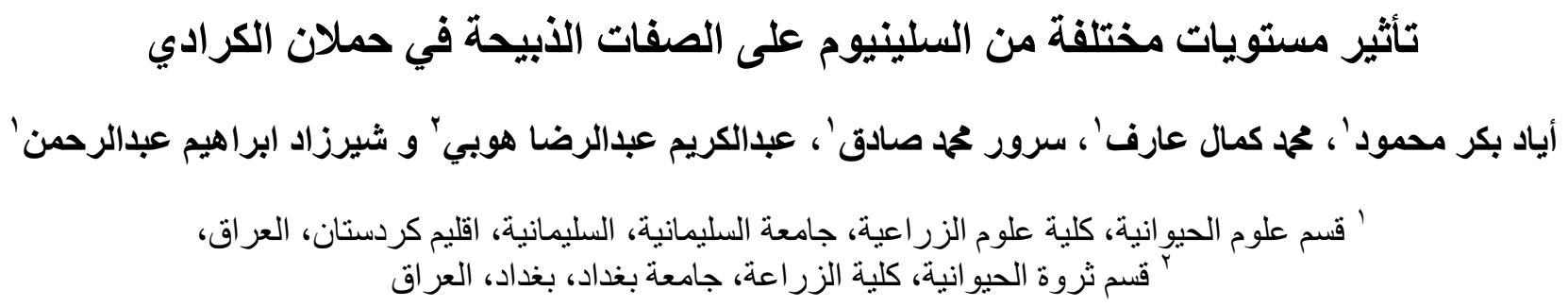

اجريت هذه الدر اسة لتقيم تأثير استخدام مستويات مختلفة من السلينيوم (سلينات الصوديوم) على الصفات الصفات الذبيحة للحملان الكرادي.

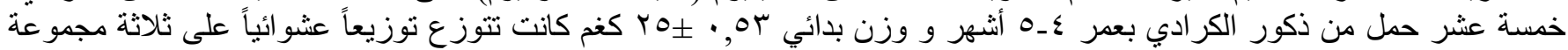

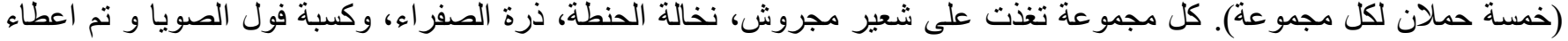

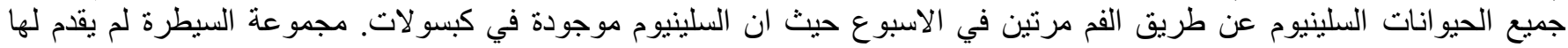

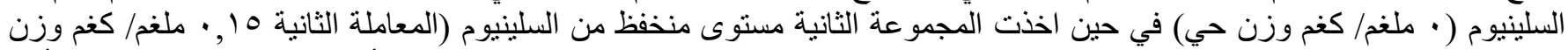

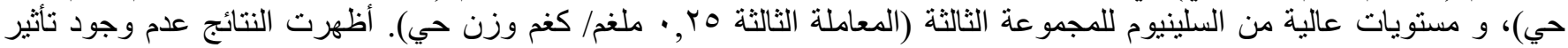




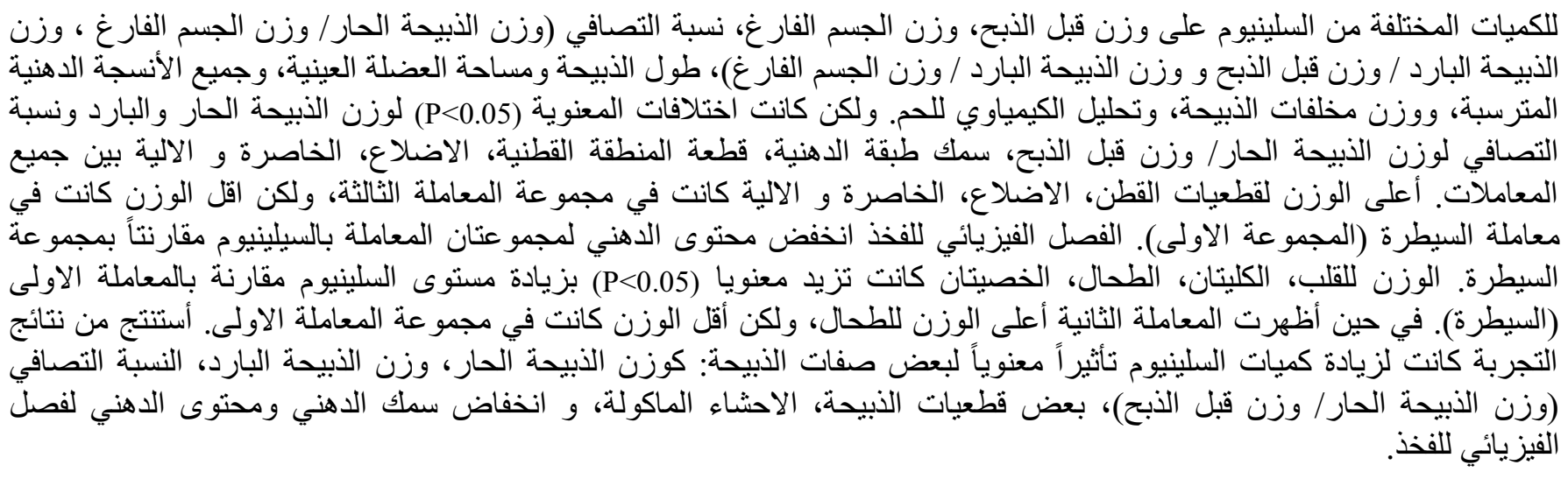

\section{Introduction}

Selenium (Se), an essential as an antioxidant defence system, plays a compatible role in the growth and health of humans and livestock on its participation in several proper enzymes and enzyme reactions (1) and (2). Selenium when included in the feed was beneficial for carcass and sensory characteristics (3). The importance of Se is mainly related with its role as an essential part of the glutathione peroxidases (GSH-Px) which supply a defence against oxidative stress by catalyzing the reduction of organic hydroperoxides that react with the selenol group of selenocysteine (4). Consequently an adequate intake of Se is needed to decrease the danger of cardiovascular disease, immunodeficiency, cancer, myopathy and other selenium deficiency syndromes (5). In ruminant, and particularly in lambs, selenium deficiency has been associated to a number of diseases, which include inhibition of immunity and white muscle disease (6).

The Se requirements for lambs have been given as 0.20 $\mathrm{mg} / \mathrm{kg}$ for lambs growing at $150 \mathrm{~g} / \mathrm{d}$ (7). Organic Se, in the form of selenomethionine is the predominant Se species in cereals and forage crops. Currently, sodium selenite is the commercial Se source used as a supplement in animal feeds.

The true digestibility of Se from diets containing selenite averages about $50 \%$ in sheep, whilst that from Seyeast would be about $66 \%$ (8). Furthermore, the uptake and assimilation of inorganic $\mathrm{Se}$ and Se-methionine are different; inorganic Se is exclusively used for the synthesis of seleno-enzymes and that which is not incorporated into functional enzymes is methylated and subsequently excreted from the body (9). Previous studies have shown that supplementing feed with inorganic Se increased $\mathrm{Se}$ concentration in edible tissues of calves (10) and lambs (11). On the other hand, recently, several researches were observed no effect of additional Se supplementation on performance of steers (12) and performance of lambs (13) and (14).
The use of inorganic Se as a possible means of enhancing carcass characteristics and chemical composition of meat, studied in recent researches not included here. Therefore, the objective of this study, which was undertaken on Karadi lambs, was to compare the effects of Se- Selenite at different levels as inorganic Se source orally given on slaughter weight, hot carcass, cold carcass, empty body weights, weight of cuts, elementary tract content weights, dressing percentages, empty dressing percentages and full dressing percentage, tissues fat weight, tissue in leg cuts percentages (Lean, Fat and Bone), lean: bone ratio, lean: fat ratio, fat thickness, rib eye area, and chemical composition of meat.

\section{Materials and methods}

\section{Animals, experimental diet and orally given selenium dose}

The experiment was conducted at farm of Animal Science Department, College of Agricultural Sciences, University of Sulaimani. Lambs were approximately 4-5 months old and had an initial body weight $25 \pm 0.53 \mathrm{~kg}$. Fifteen individual lambs were randomly divided into three groups (5 lambs for each group), control without adding selenium (T1), low selenium dose $(0.15 \mathrm{mg} / \mathrm{kg}$ body weight of lambs) (T2) and high dose (T3) $(0.25 \mathrm{mg} / \mathrm{kg}$ body weight of lambs). Selenium was put in empty gelatin capsules and was orally given to the lambs twice a week. The concentrate diets formulated to have a similar level of protein and metabolize energy were given to all groups at $3 \%$ of lamb's body weight. Lambs were fed a total mixed ration containing concentrate mixture (40\% barley, $29 \%$ wheat bran, $15 \%$ soybean meal, $15 \%$ yellow corn and $1 \%$ common salt). The lambs were offered concentrate mixtures $(3 \%$ of $\mathrm{BW})$, but wheat straw were offered $a d$ libitum. Experimental period lasted for 90 days. Lambs were raised under similar environmental and management conditions. The lambs were purchased from a known local contractor and they were individually housed in pens $(1 \mathrm{x}$ 
$1.5 \mathrm{~m})$ at the animal production farm and that allowed access to diets supplied in metal buckets, water was available at all time and the diets were gradually introduced to the lambs over a period of two weeks before the start of the experiment and all lambs were weighed weekly at 9.00 a.m. by hanging balance (100 gm sensitivity). Lambs were kept in clean and hygienic environment.

The formulation and chemical composition of concentrate diet were presented in Table (1). The chemical composition of concentrate feeds was calculated according to $\mathrm{NRC}(7)$.

\section{Animal slaughtering}

At the end of the experiment, the Karadi ram lambs were fasting for $16 \mathrm{~h}$, with access to water and weighed quickly preceding slaughter. Three ram lambs were slaughtered for each treatment group as indicated by the Islamic method at the creature department abattoir without anaesthetization. Draining was done by a cut on the jugular wrinkle at the occipito - atlantal both carotid course, jugular veins and sometimes the trachea, intersection near the head separating throat and spinal strain. After slaughter, the head was expelled at the atlanto-occipital joint and fore and rear feet at the carpal and tarsal joints, individually. The carcass was mostly cleaned on the floor and after that hanged in the racks by the rear legs and cleaning was finished. Quickly subsequent to cleaning gutting was completed and the remains and non - carcass segments were weighed. Hot carcass included kidney and kidney fat, consumable offal contained testicles, spleen, liver, heart, lung and trachea, and unappetizing offal constitute, head, feet, and skin were weighed. Omental, mesenteric, and cardiovascular fat were isolated and weighed. The gastrointestinal tract was measured, then discharged of their, washed and reweighed to encourage count of empty body weight by subtracting the weight of the gut from the slaughter weight. The dressing percentage was expressed on slaughter body weight (SBW) as well as on empty body weight (EBW) basis according to the following equation by Rouse et al. (15):

Dressing Percentage $\%=\mathrm{HCW}$ or $\mathrm{CCW} / \mathrm{SBW}$ or $\mathrm{EBW} \times 100$

\section{Carcass whole cut measuring}

The left carcasses were placed in the chiller at $4{ }^{\circ} \mathrm{C}$ for $24 \mathrm{~h}$, after that the cold carcass was measured, and then kidney and pelvic fat were evacuated and weighed independently. The body was partially along the vertebral section into two parts by hand saw; the left half of the carcass was cut into nine whole cuts included (leg, loin, rack, neck, shoulder, breast, foreshank, flank, tail fat). All wholesale cuts were weight separately at once. The fat thickness was measured by digital vernier and longissimus dorsi muscle at the $12^{\text {th }}$ rib was dictated by following the muscle rib area on semitransparent waxed paper, and the area was measured by a placom advanced planimeter.

\section{Physical dissection of Leg and non carcass fat}

Left legs were dissected totally into lean, fat and bone for each treatment. The three parts were measured independently to decide their rates. Non carcass fat is the whole of the omental, mesenteric, pelvic, kidney, and cardiovascular fat was weighed.

\section{Chemical analysis of meat}

After triplicate samples were given from each leg in particular of the muscle Biceps Femoris for chemical analysis. Ash was determined according to the official method of AOAC International (16), method 942.05, Moisture according to the AOAC (16) official method 934.01, Fat (crude) or Ether extract according to the AOAC (16) official method 920.39.

\section{Statistical analysis}

The obtained data were analyzed according to statistical analysis system users guide XLSTAT for one way analysis of variance (17). Separations among means were carried out by using Duncan's multiple range tests (18).

The statistical model for analysis of variance was:

$\mathrm{Yij}=\mu+\mathrm{Ai}+\mathrm{eij}$

Where: $Y i j=$ observation $j$ in level $i$ of treatment $A(j=$ $1, \ldots, 5), \mu=$ the overall mean, $\mathrm{Ai}=$ the effect of level $\mathrm{i}$ of treatment $\mathrm{A}(\mathrm{i}=1,2,3)$, eij $=$ random error associated with means $=0$ and variance $\delta 2 \mathrm{e}$.

Table 1: Formulation and chemical composition of experimental diet

\begin{tabular}{lc}
\hline Ingredients & $(\mathrm{g} / \mathrm{kg} \mathrm{DM})$ \\
\hline Barley & 400 \\
Wheat bran & 290 \\
Yellow corn & 150 \\
Soybean meal & 150 \\
Salt (Nacl) & 10 \\
\hline Total & $1000 \mathrm{~g}$ \\
\hline Chemical Composition* & $(\mathrm{g} / \mathrm{kg} \mathrm{DM})$ \\
\hline Dry Matter (DM) & 930.23 \\
Organic Matter (OM) & 910.5 \\
Crude Protein (CP) & 150.5 \\
Crude Fiber (CF) & 70.47 \\
Ether Extract (EE) & 30.79 \\
Nitrogen Free Extract (NFE) & 670.8 \\
Metabolizable Energy ME (MJ/kg) ** & 12.5 \\
\hline * Calculated mathematically according to the NRC (7), \\
**ME (MJ/ kg DM)=0.012 CP +0.031 EE +0.005 CF \\
+0.014 NFE (19).
\end{tabular}




\section{Results}

The result presented in (Table2) revealed that the effect of the different amount of Selenium (Se) (Sodium Selenit) on slaughter weight and carcass characteristics of Karadi ram lambs. There were no significant differences among all treatment groups in slaughter weight (SW), empty body weight (EBW), dressing percentages based on hot carcass weight $(\mathrm{HCW})$ and on empty body weight $(\mathrm{EBW})$, cold carcass weight $(\mathrm{CCW})$ on SW or EBW, carcass length and rib eye area, but significant $(\mathrm{P}<0.05)$ differences in hot carcass weight $(\mathrm{HCW})$, cold carcass weight $(\mathrm{CCW})$, dressing percentage of $\mathrm{HCW} / \mathrm{SW}$ and fat thickness among treatments. The highest value of $\mathrm{HCW}, \mathrm{CCW}$, and dressing percentage $\mathrm{HCW} / \mathrm{SW}$ was found in T3 or high-level intake selenium (Se), but the lowest values were above mentioned in control groups (T1). While, the T2 or low- level Se intake was intermediated between control groups (T1) and high level Se intake (T3), for these parameters such as $\mathrm{HCW}, \mathrm{CCW}$ and dressing percentage as represented as $\mathrm{HCW} / \mathrm{SW}$. The lowest fat thickness was found significant $(\mathrm{P}<0.05)$ in $\mathrm{T} 3$, but the highest values of fat thickness were found in T2 and T1. While, the control groups T1 and lowlevel Se intake were not significant $(\mathrm{P}>0.05)$ for fat thickness.

The results of left half carcass weight and whole cuts are presented in Table (3). The left half carcass weight, leg, shoulder, breast, neck, fore shank were not significant among treatments, except the loin, rack, flank and fat tail were significant $(\mathrm{P}<0.05)$ differences among treatments. The highest weight of loin, rack, flank and fat tail was found in T3, but the lowest mentioned values had seen in control groups (T1). The differences between Se treated both groups ( high and low levels Se intake) were not significant $(\mathrm{P}>0.05)$ for loin cut. Another one, at the same not significant $(\mathrm{P}>0.05)$ differences between $\mathrm{T} 1$ control and T2 low levels Se intake by Karadi lambs for fat tail.

The adipose fat tissues included mesenteric fat, omental fat, cardiac fat, kidney and pelvic fat were presented in Table (4) together with carcass offal weights such as; feet, head, wool with skin, empty rumen and empty intestines. All adipose fat tissues and carcass offal weights were not significant among treatment groups. Furthermore, the edible organ weights have been presented in the same Table (4). The heart, kidneys, spleen and testicular weight were increased significantly $(\mathrm{P}<0.05)$ by increased levels of $\mathrm{Se}$ compared to the control groups (T1). The heart and testicular weights did not significant between low and high levels of Se intake. The kidney weight has not statistically different between control groups (T1) and low levels Se intake (T2). The higher weight in liver was found in (T3), but the lower weight was obtained in the low levels Se intake (T2). While, the T1 (control) was intermediated between other treatment groups. There were not significant among all treatment in lung weight. The low levels of Se intake (T2) showed a higher weight of the spleen and the lowest weight was in (T1).

As shown in Table (5), the physical dissection of leg components which includes; lean and bone did not significantly differ among treatments, only the fat $\%$ was reduced in both Se treatments compared to control groups. While the fat percent of physical component did not significantly between $\mathrm{T} 2$ and $\mathrm{T} 3$.

Table 2: Effect of different levels of selenium on slaughter weight and carcass characteristics (Mean $\pm \mathrm{SE})$

\begin{tabular}{lccc}
\hline Items & T1 & T2 & T3 \\
& Control group & Low level Se & High level Se \\
\hline SW $(\mathrm{kg})$ & $40.200 \pm 0.693 \mathrm{a}$ & $40.300 \pm 0.569 \mathrm{a}$ & $41.500 \pm 0.289 \mathrm{a}$ \\
EBW $(\mathrm{kg})$ & $36.100 \pm 0.643 \mathrm{a}$ & $37.800 \pm 0.611 \mathrm{a}$ & $37.300 \pm 1.115 \mathrm{a}$ \\
$\mathrm{HCW}(\mathrm{kg})$ & $19.000 \pm 0.351 \mathrm{~b}$ & $19.900 \pm 0.115 \mathrm{ab}$ & $21.100 \pm 0.404 \mathrm{a}$ \\
CCW $(\mathrm{kg})$ & $18.740 \pm 0.503 \mathrm{~b}$ & $19.700 \pm 0.379 \mathrm{ab}$ & $20.910 \pm 0.666 \mathrm{a}$ \\
\hline Dressing percentage (\%) & & & \\
\hline HCW/SW & $47.263 \pm 1.597 \mathrm{~b}$ & $49.379 \pm 0.422 \mathrm{ab}$ & $50.843 \pm 0.230 \mathrm{a}$ \\
HCW/EBW & $52.631 \pm 1.837 \mathrm{a}$ & $52.645 \pm 0.963 \mathrm{a}$ & $56.568 \pm 1.656 \mathrm{a}$ \\
CCW/SW & $46.617 \pm 1.741 \mathrm{a}$ & $48.883 \pm 0.411 \mathrm{a}$ & $50.385 \pm 1.887 \mathrm{a}$ \\
CCW/EBW & $51.911 \pm 1.856 \mathrm{a}$ & $52.116 \pm 1.491 \mathrm{a}$ & $56.059 \pm 2.897 \mathrm{a}$ \\
Carcass length (cm) & $73.0 \pm 1.0 \mathrm{a}$ & $73.5 \pm 0.557 \mathrm{a}$ & $71.0 \pm 1.155 \mathrm{a}$ \\
Rib eye area (cm & $12.37 \pm 0.286 \mathrm{a}$ & $12.92 \pm 0.526 \mathrm{a}$ & $13.37 \pm 0.399 \mathrm{a}$ \\
Fat thickness $(\mathrm{mm})$ & $2.01 \pm 0.066 \mathrm{a}$ & $2.15 \pm 0.100 \mathrm{a}$ & $1.52 \pm 0.053 \mathrm{~b}$ \\
\hline
\end{tabular}

$\mathrm{SW}=$ Slaughter weight, $\mathrm{EBW}=$ Empty Body weight, $\mathrm{HCW}=$ Hot Carcass Weight, $\mathrm{CCW}=$ Cold Carcass Weight, $\mathrm{T} 1=$ control group, $\mathrm{T} 2=$ low level selenium $(\mathrm{Se})$ intake $0.15 \mathrm{mg} / \mathrm{kg}$ body weight, $\mathrm{T} 3=$ high level Se intake $0.25 \mathrm{mg} / \mathrm{kg}$ body weight. Means followed by the different letter within a row are significant $(\mathrm{P}<0.05)$. 
Table 3: Effects of different level of selenium on whole carcass cuts (Mean $\pm \mathrm{SE}$ )

\begin{tabular}{lccc}
\hline Whole cut carcass $(\mathrm{g})$ & T1 & T2 & T3 \\
& Control group & Low level Se & High level Se \\
\hline Left half carcass weight & $9270 \pm 779.4 \mathrm{a}$ & $9837 \pm 645.4 \mathrm{a}$ & $10542 \pm 353.5 \mathrm{a}$ \\
Leg & $2860.7 \pm 52.9 \mathrm{a}$ & $2951.9 \pm 33.6 \mathrm{a}$ & $2991 \pm 8.9 \mathrm{a}$ \\
Loin & $469.7 \pm 16.2 \mathrm{~b}$ & $650.3 \pm 31.01 \mathrm{a}$ & $611.3 \pm 1.89 \mathrm{a}$ \\
Rack & $872 \pm 10.79 \mathrm{c}$ & $966.8 \pm 16.26 \mathrm{~b}$ & $1070 \pm 10.12 \mathrm{a}$ \\
Shoulder & $1731.4 \pm 70.41 \mathrm{a}$ & $1780 \pm 66.67 \mathrm{a}$ & $1898.7 \pm 52.068 \mathrm{a}$ \\
Breast & $646.5 \pm 58.8 \mathrm{a}$ & $685.6 \pm 64.9 \mathrm{a}$ & $641.7 \pm 40.3 \mathrm{a}$ \\
Neck & $575.80 \pm 28.25 \mathrm{a}$ & $583.5 \pm 12.58 \mathrm{a}$ & $586.7 \pm 7.75 \mathrm{a}$ \\
Fore shank & $422.30 \pm 6.5 \mathrm{a}$ & $478 \pm 1.0 \mathrm{a}$ & $482.3 \pm 33.5 \mathrm{a}$ \\
Flank & $224.8 \pm 4.91 \mathrm{c}$ & $301.5 \pm 10.86 \mathrm{~b}$ & $399.3 \pm 5.49 \mathrm{a}$ \\
Fat tail & $1468.7 \pm 83.5 \mathrm{~b}$ & $1439.7 \pm 48 \mathrm{~b}$ & $1861 \pm 132.5 \mathrm{a}$ \\
\hline
\end{tabular}

$\mathrm{T} 1=$ control groups, $\mathrm{T} 2=$ low level selenium $(\mathrm{Se})$ intake $0.15 \mathrm{mg} / \mathrm{kg}$ body weight, $\mathrm{T} 3=$ high level Se intake $0.25 \mathrm{mg} / \mathrm{kg}$ body weight. Means followed by the different letter within a row are significant $(\mathrm{P}<0.05)$.

Table 4: Effects of different level of selenium on fat tissue, carcass offal and edible organ weights (Mean $\pm \mathrm{SE}$ )

\begin{tabular}{lccc}
\hline Parameters & $\begin{array}{c}\text { T1 } \\
\text { Control group }\end{array}$ & $\begin{array}{c}\text { T2 } \\
\text { Low level Se }\end{array}$ & $\begin{array}{c}\text { T3 } \\
\text { High level Se }\end{array}$ \\
\hline Fat tissues (g) & & & \\
\hline Mesenteric fat & $329.3 \pm 3.943 \mathrm{a}$ & $318.3 \pm 10.214 \mathrm{a}$ & $302.7 \pm 7.193 \mathrm{a}$ \\
Omental fat & $443 \pm 11.46 \mathrm{a}$ & $448.3 \pm 6.93 \mathrm{a}$ & $450.3 \pm 6.11 \mathrm{a}$ \\
Cardiac fat & $72.4 \pm 1.518 \mathrm{a}$ & $69.7 \pm 0.569 \mathrm{a}$ & $75 \pm 3.329 \mathrm{a}$ \\
Kidney and Pelvic fat & $232 \pm 6.658 \mathrm{a}$ & $234.3 \pm 5.807 \mathrm{a}$ & $250 \pm 9.805 \mathrm{a}$ \\
\hline Carcass offal (g) & & & \\
\hline Feet & $932 \pm 6.0 \mathrm{a}$ & $880.7 \pm 38.0 \mathrm{a}$ & $945 \pm 64.5 \mathrm{a}$ \\
Head & $2116.3 \pm 37.8 \mathrm{a}$ & $2183.6 \pm 102.5 \mathrm{a}$ & $2022.5 \pm 103.5 \mathrm{a}$ \\
Wool with skin weight & $4363.3 \pm 140.2 \mathrm{a}$ & $4369.2 \pm 100.5 \mathrm{a}$ & $4486.7 \pm 320.9 \mathrm{a}$ \\
Empty rumen & $1370 \pm 36.0 \mathrm{a}$ & $1298.9 \pm 7.5 \mathrm{a}$ & $1435.7 \pm 116.5 \mathrm{a}$ \\
Empty intestines & $1243.4 \pm 67.5 \mathrm{a}$ & $1198 \pm 20.0 \mathrm{a}$ & $1375 \pm 50.0 \mathrm{a}$ \\
\hline Edible organ weight (g) & & & \\
\hline Heart & $161 \pm 4.0 \mathrm{~b}$ & $185.5 \pm 3.51 \mathrm{a}$ & $182 \pm 2.0 \mathrm{a}$ \\
Kidneys & $98.7 \pm 1.5 \mathrm{~b}$ & $90 \pm 1.0 \mathrm{~b}$ & $113.3 \pm 6.52 \mathrm{a}$ \\
Liver & $744 \pm 68.0 \mathrm{ab}$ & $725.7 \pm 17.5 \mathrm{~b}$ & $773.5 \pm 68.7 \mathrm{a}$ \\
Lungs & $476 \pm 23.0 \mathrm{a}$ & $462.7 \pm 4.0 \mathrm{a}$ & $449 \pm 18.0 \mathrm{a}$ \\
Spleen & $91 \pm 17.5 \mathrm{c}$ & $138 \pm 2.5 \mathrm{a}$ & $123.3 \pm 12.00 \mathrm{~b}$ \\
Testicular & $167 \pm 30.5 \mathrm{~b}$ & $188 \pm 20.5 \mathrm{a}$ & $189.7 \pm 5.5 \mathrm{a}$ \\
\hline
\end{tabular}

$\mathrm{T} 1=$ control group, $\mathrm{T} 2=$ low level selenium $(\mathrm{Se})$ intake $0.15 \mathrm{mg} / \mathrm{kg}$ body weight, $\mathrm{T} 3=$ high level Se intake $0.25 \mathrm{mg} / \mathrm{kg}$ body weight. Means followed by the same letter within a row are not significant $(\mathrm{P}<0.05)$.

Table 5: Effects of different level of selenium on physical dissection of legs (Mean \pm SE)

\begin{tabular}{lccc}
\hline Components \% & T1 & T2 & T3 \\
& Control group & Low level Se & High level Se \\
\hline Lean & $59.48 \pm 1.43 \mathrm{a}$ & $61.74 \pm 1.49 \mathrm{a}$ & $61.88 \pm 1.15 \mathrm{a}$ \\
Bone & $20.15 \pm 0.132 \mathrm{a}$ & $21.22 \pm 0.808 \mathrm{a}$ & $20.33 \pm 0.776 \mathrm{a}$ \\
Fat & $20.37 \pm 0.531 \mathrm{a}$ & $17.04 \pm 0.686 \mathrm{~b}$ & $17.79 \pm 0.266 \mathrm{~b}$ \\
\hline
\end{tabular}

$\mathrm{T} 1=$ control group, $\mathrm{T} 2=$ low level selenium(Se) intake $0.15 \mathrm{mg} / \mathrm{kg}$ body weight, $\mathrm{T} 3=$ high level Se intake $0.25 \mathrm{mg} / \mathrm{kg}$ body weight. Means followed by the different letter within a row are significant $(\mathrm{P}<0.05)$. 
Table (6) presented the result of the chemical composition of meat (moisture, protein, fat and ash\%) of
Karadi ram lambs. It showed no significant differences among all treatment groups.

Table 6: Effects of different level of selenium on the chemical composition of the muscle (Biceps Femoris) (Mean $\pm \mathrm{SE}$ )

\begin{tabular}{lccc}
\hline Component of meat (\%) & T1 & T2 & T3 \\
& Control group & Low level Se & High level Se \\
\hline Moisture & $73.850 \pm 1.151 \mathrm{a}$ & $73.100 \pm 1.386 \mathrm{a}$ & $73.050 \pm 1.076 \mathrm{a}$ \\
Protein & $21.950 \pm 0.814 \mathrm{a}$ & $22.300 \pm 0.362 \mathrm{a}$ & $22.700 \pm 0.416 \mathrm{a}$ \\
Fat & $2.100 \pm 0.006 \mathrm{a}$ & $2.190 \pm 0.072 \mathrm{a}$ & $2.450 \pm 0.212 \mathrm{a}$ \\
Ash & $1.270 \pm 0.118 \mathrm{a}$ & $1.260 \pm 0.108 \mathrm{a}$ & $1.380 \pm 0.076 \mathrm{a}$ \\
\hline
\end{tabular}

$\mathrm{T} 1=$ control group, $\mathrm{T} 2=$ low level selenium $(\mathrm{Se})$ intake $0.15 \mathrm{mg} / \mathrm{kg}$ body weight, $\mathrm{T} 3=$ high level Se intake $0.25 \mathrm{mg} / \mathrm{kg}$ body weight. Means followed by the same letter within a row are not significant $(\mathrm{P}<0.05)$.

\section{Discussion}

\section{Effect of Selenium intake on carcass characteristics}

In this research, the high level of Selenium intake showed no significant differences in most traits studied except hot carcass weight $(\mathrm{HCW})$, cold carcass weight (CCW), dressing percentage expressed of $\mathrm{HCW} / \mathrm{SW}$. Lambs given high levels Se had improved $(\mathrm{P}<0.5$, Table 2$)$ the dressing percentage $(\mathrm{HCW} / \mathrm{SW})$. The result of the present study was similar to the reported by HernandezCalva et al (20). These differences were due to the higher proportion of muscle tissue in hot carcass weight in particular in the regions of the leg, loin and rack $(\mathrm{P}<0.05$, Table 3 and 4). However, the fat thickness was decreased in the lambs given a high dose of Se. Our results were similar to finding to authors (21) reported that the Se, $\mathrm{Zn}$ and vitamin $\mathrm{E}$ given orally to growing ram-lambs induced decrease content of fat thickness on loin-eye and fat thickness over ribs. However, in this study, the hot carcass dressing percentage was evident, due to increased muscle tissues that made up the leg, loin and rack in the groups orally high dose of Se. A probable reason is that the mineral potential can motivate hypertrophy in type 1 fibers skeletal muscles (22). It is well-known that Se has a specific activity of enzymes, which converts the source from trisulfide selenoglutation, which is degraded in the liver to form selenide (23). The selenide finally is used for the synthesis of selenoproteins like GSH-Px. This enzyme when integrated with skill improves muscle and protects against peroxidation. But other parameters showed in table (2) not significant among treatments were similar to the results these researchers found that dietary Se had no effect on carcass dressing percentage (24), (25) and slaughter weight, empty body weight and dressing percentage of empty body weight (14). It seems in this research that rib eye area numerically increased in lambs given high level of Se, but the statistical analysis did not show differences among treatment groups. The rib eye area is also the major muscle in the loin, which is the most valuable wholesale cuts in the carcass. The rib eye area is related to carcass weight (hot carcass weight, Table 2) was heavier carcasses, so have a larger rib eye area in lambs fed high level Se. Another one, the high levels of Se due to decrease fat thickness compared to the control group, this result was similar to findings by (21).

\section{Impact of inorganic Se in wholesale cuts, fat tissue, carcass offal and edible organ weights}

The influence of the high Se intake was significantly increased the loin, rack, flank and fat tail due to impact of accumulation of Se intake, duration periods, and balanced Se in feeds as compared other treatment especially control groups. The numerical increased of leg weight was noticed in high levels of Se intake. However, our research did not detect Se contents in feeds and meat. So, for example, the highest weight of the leg was (2991 g), whereas the lowest $(2860.7 \mathrm{~g})$ was in the control group. The variation in muscle mass was primarily due to differences in the total number of muscle fibers. Possibly the evolutionary increase in muscle fiber size was limited by physiological status in that normal cell function was maintained only as long as a certain limit in cell size was not exceeded (26). In contrast, many researchers reported that the inorganic selenium on visceral organs yield, wholesale cuts proportion (foreshank, neck and shoulder, rack, loin, and leg), the proportion of meat, bone and fat in the carcass and chemical composition of muscle (meat) were not affected (Tables 6) by dietary Se supplementation in Karadi ram lambs. Similar to our findings with these researchers (25) observed no significant effect of Se supplementation (sodium selenite, 0.3 or 0.45 $\mathrm{ppm})$ to the basal diet $(0.13 \mathrm{ppm})$ on carcass yield. Similarly, Lee et al. (12) observed no significant changes in carcass characteristics (yield and composition) of Han woo steers with dietary Se (sodium selenite, $0.9 \mathrm{mg} / \mathrm{kg} \mathrm{DM}$ ) supplementation. The higher weight of fat tail in high dose Se found in the current study was due to increasing the slaughter weight in this group.

On the other hand, oral intake of inorganic Se by rams for 90 days has induced some significant changes in morphology of the lambs in the present study: heart, 
kidneys, liver, spleen and testicle weights were significantly increased in lambs received Se, particularly in lambs orally given with $0.25 \mathrm{mg} / \mathrm{kg}$ body weight. The high levels of Se intake was not affected any change in inner fat such as mesenteric, omental, cardiac and pelvic fat due to selenium administration would induce changes in fat distribution by promoting carcass fat deposits include fat tail (Table 2) (whose the proportions tended to increase in supplemented lambs) instead of inner fat formation; as internal fat was more often submitted to oxidative stress, this modification of the fat repartition would be beneficial to growth by promoting fat energy utilization. Moreover, the improvement of antioxidant systems illustrated by increases of GSH-Px activity in the supplemented groups would directly limit the oxidation of internal fat and indirectly enhance its redistribution into carcass fat deposits (27). Furthermore, the increased testical weight due to the development of gonads would be related to the reduction of spermatozoid lethality and consequently to the improvement of spermatogenesis. In this study, it was noticed no differences between inorganic Se and control groups in offal carcass weight (feet, head, wool with skin weight, empty rumen, empty intestines. This result was an agreement with the results found by (14).

\section{Influence of sodium Selenite on physical dissection of legs and chemical composition of the muscle (Bicpis Femoris)}

The results of this work showed that the percentage of fat in the physical dissection of leg tissues significantly $(\mathrm{P}<0.5$, Table 5) reduced in $\mathrm{T} 2$ and $\mathrm{T} 3$ as compared to the control groups. Our results were similar to the results of the finding many authors (21) who reported that the Se, $\mathrm{Zn}$ and vitamin $\mathrm{E}$ treated rams contained significantly less fat in the leg, less fat thickness over ribs and less fat thickness over loin-eye than non treated rams. In comparison to the lambs received high level Se significantly decreased the fat in leg (Table 5). In the study of authors (21) who indicated that $\mathrm{Se}, \mathrm{Zn}$ and vitamin $\mathrm{E}$ administered orally to growing ramlambs induced a decrease in the total cholesterol content of blood and meat and increase the high density lipoprotein fractions level in blood. High levels Se intake by lambs, the carcasses were characterized by $61.88,20.33$ and $17.79 \%$ of muscle, and bone, and adipose tissue, respectively. In contrast, had no any effect of sodium selenite on carcass in bulls by researchers (28) previously reported no effects of Se supplementation for the slaughter performance of Charolais bulls managed through different feeding strategies. Netto et al. (29) observed no significant differences in carcass yield of steers from the Brangus breed receiving a diet supplemented with Se at $2 \mathrm{mg} \mathrm{kg}^{-1}$ $\mathrm{DM}$ in the form of sodium selenite $(\mathrm{Na} 2 \mathrm{SeO} 3)$.

The chemical composition of meat legs did not any differences between lambs received Se and control groups.
However, numerically increased the protein, fat and ash content in meat lambs high dose selenium intake. This result was confirmed by (14) who reported that inorganic (Se) source in the form of sodium selenite at different levels did not show impact on animal performance in growing Nellore ram lambs had no influence on carcass characteristics including chemical composition of meat.

Finally, during our work for 90 days all animals have a good health without any change problem towards the lambs orally intake high or low levels inorganic selenium. These levels of sodium selenite we used in this study were within the reference values used by (30) who demonstrated that lambs which given 0 and $1 \mathrm{mg}$ of $\mathrm{Se} / \mathrm{kg} \mathrm{BW}$ as sodium selenite did not have remarkable clinical signs of disease or gross lesions.

\section{Conclusion}

The effect of the different amount of Sodium Selenit orally given to Karadi ram lambs had significantly increased in some carcass traits such as hot carcass weight ( $\mathrm{HCW}$ ), cold carcass weight (CCW), dressing percentage of $\mathrm{HCW} / \mathrm{SW}$, carcass cuts (loin, rack, flank and fat tail), edible organ (heart, kidneys, spleen and testicular weight). But the high levels of Se significantly reduced in fat thickness and fat percent in the physical dissection of legs. In contrast, lambs received high dose Se did not showed any differences between all treatments in slaughter weight (SW), empty body weight (EBW), dressing percentages like hot carcass weight $(\mathrm{HCW})$ on empty body weight (EBW), cold carcass weight (CCW) on SW or EBW, carcass length and rib eye area, left half carcass weight, whole cuts (leg, shoulder, breast, neck, fore shank), adipose fat tissues (mesenteric, omental, cardiac, pelvic fat), carcass offal weights (feet, head, wool with skin, empty rumen, empty intestine) and Chemical composition of meat (moisture, protein, fat and ash $\%$ ) of Karadi ram lambs.

\section{References}

1. Rayman MP. The use of high-selenium yeast to raise selenium status: how does it measure up? Brit J Nutr. 2004;92:557-573.

2. Surai PF. Selenium distribution and reserves in human body. In: Selenium in Nutrition and Health. NottinghamUniversity Press, Nottingham, UK, 2006.pp. 161-171.

3. Liu Q, Lanari MC, Schaefer, DM. A review of dietary vitamin E supplementation for improvement of beef quality. J Anim. Sci. 1995;73:3131-3140.

4. Hardy G, Hardy I. Selenium: The Se-XY nutraceutical. Nutrition. 2004:20:590-593.

5. Hartikainen H.. Biochemistry of selenium and its impact on food chain quality and human health. J Trace Elem Med Biol. 2005;18:309-318.

6. Rock MJ, Kincaid RL, Carstens GE. Effects of prenatal source and level of dietary selenium on passive immunity and thermometabolism of newborn lambs. Small Rumin Res. 2001;40:129-138. 
7. NRC. Nutrient Requirements of Small Ruminants: Sheep, Goats, Cervids, and New World Camelids. National Academy Press, Washington, DC. 2007.

8. Weiss WP. Selenium sources for dairy cattle. In: Proceedings tri-state dairy nutrition conference. 2005; pp: 61-71. Fort Wayne, IN, USA.

9. Deagen JT, Butler JA, Beilstein MA, Whanger PD. Effects of dietary selenite, selenocysteine, and selenomethionine on selenocysteine lyase and glutathione peroxidase activities and on selenium levels in rat tissues. J Nutr. 1987;117:91-98.

10. Pavlata L, Illek J, Pechova A. Blood and tissue selenium concentrations in calves treated with inorganic or organic selenium compounds - a comparison. Acta Veterin Brno. 2001;70:19-26.

11. Molnar J, Macpherson A, Molnar P. The effects of selenium supplementation in feeding of lambs. Acta Alimentaria. 1998;27:167179.

12. Lee SH, Park BY, Yeo JM, Sung SL, Lee JH, Ha JK, Kim WY. Effects of Different Selenium Sources on Performance, Carcass Characteristics, Plasma Glutathione Peroxidase Activity and Selenium Deposition in Finishing Hanwoo Steers. Asian-Aust J Anim Sci. 2007;20 (2):229-236

13. Dominguez-Vara IA, Gonzalez-Munoz SS, Pinos-Rodriguez JM, Borquez-Gastelum JL, Barcena- Gama R, Mendoza-Martinez G, Zapata LE, Landois-Palencia LL. Effects of feeding selenium-yeast and chromium-yeast to finishing lambs on growth, carcass characteristics, and blood hormones and metabolites. Anim Feed Sci Technol. 2009;152:42-49.

14. Sushma K, Raman RY, Nalini KN, Baswa RP, Raghunandan T, Sridhar K. Effect of selenium supplementation on performance, cost economics, and biochemical profile of Nellore ram lambs. Vet World. 2015;8(9):1150-1155.

15. Rouse GH, Topel DG, Vetter RL, Rust RE, Wickersham TW. Carcass composition of lamb at different stage of development. J Anim Sci. 1970;31:846-855.

16. AOAC. Official methods of analysis. ( $17^{\text {th }}$ Ed.) Association of official analytical chemist Inc. Arlington, Virginia, USA. 2002.

17. Addinsoft. Xlstat, analyse de données et statistique avec ms excel. Addinsoft; 2007. Ny, usa. Url Available: http://www.xlstat.com/.

18. Duncan DB. Multiple ranges and multiple " $\mathrm{f}$ " test. Biometrics. 1955;11:1-12.

19. MAFF. Ministry of Agriculture, Fisheries and Food Department of Agriculture and Fisheries for Scotland. Energy allowance and feeding system for ruminants, Technical Bulletin 33. Her Majesty's Stationary Office, London. 1975.
20. Hernandez-Calva LM, Ramirez-Bribiesca JE, Guerrero-Legarreta I, Hernandez-Cruz L, Avendaño-Reyes L, Vara ID, McDowell LR. Influence of dietary magnesium and selenium levels in finishing diets on growth performance and carcass meat quality of feedlot Pelibuey lambs. Arch Fur Tierzuch Arch Anim Breed. 2013;56:303-314.

21. Gabryszuk M, Karina H, Klewiec J. Rearing, fattening performance and slaughter indicators of lambs after selenium, zinc and vitamin E supplementation. Archiv Tierzucht. 2009;52(3):309-320.

22. Rannem T, Ladefoged K, Hylander E, Christiansen J, Laursen H, Kristensen JH, Linstow M, Beyer N, Liguori R, Dige-Petersen H, Jensen BH, Jarnum S. The effect of selenium supplementation on skeletal and cardiac muscle in selenium-depleted patients. J Parent Enter Nutr. 1995; 19:351-355.

23. Scharauzer GN. Selenomethionine: a review of its nutritional significance, metabolism and toxicity. J Nutr. 2000;7:1653-1656.

24. Lawler, TL, Taylor JB, Finley JW, Caton JS. Effect of supranutritional and organically bound selenium on performance, carcass characteristics, and selenium distribution in finishing beef steers. J Anim Sci. 2004;82:1488-1493.

25. Vignola G, Lambertini L, Mazzone G, Giammarco M, Tassinari M, Martelli G, Bertin G. Effects of selenium source and level of supplementation on the performance and meat quality of lambs. Meat Sci. 2009;81:678-685.

26. Rehefeldt C, Walther K, Albrecht E, Nurnberg G, Renne V, Banger L. Intrinsic properties of muscle satellite cells are changed in response to long-term. Selection of mice for different growth traits. Cell and tissue Res. 2002;310:339-348.

27. Surai PF. Organic selenium: benefits to animals and humans, a biochemist's view. In: Biotechnology in the Feed Industry. Proceedings of Alltech's 16th Annual Symposium. T.P. Lyons and K.A. Jacques (eds). Nottingham University Press, Nottingham. 2000; pp:205-260.

28. Cozzi G, Prevedello P, Stefani AL, Piron A, Contiero B, Lante A, Gottardo F, Chevaux E. Effect of dietary supplementation with different sources of selenium on growth response, selenium blood levels and meat quality of intensively finished Charolais young bulls. Animal. 2011;5:1531-1538.

29. Netto AS., Zanetti MA, Del Claro GR, Vilela FG, de Melo MP, Correa LB, Pugine SMP. Copper and selenium supplementation in the diet of Brangus steers on the nutritional characteristics of meat. R Bras Zootec. 2013;42:70-75.

30. Tiwary AK, Bryan LS, Kip EP, Lynn FJ, Jeffery OH. Comparative toxicosis of sodium selenite and selenomethionine in lambs. J Vet Diagn Invest. 2006;18:61-70. 